\title{
Escherichia coli in the Surface Waters and in Oysters of Two Cultivations of Guaratuba Bay - Paraná - Brazil
}

\author{
Helenita Catharina Dalla-Lana Forcelini*, Hedda Elisabeth Kolm and Theresinha \\ Monteiro Absher \\ Centro de Estudos do Mar; Universidade Federal do Paraná; Av. Beira Mar s/n; Pontal do Paraná - PR - Brasil
}

\begin{abstract}
The present work aimed to evaluate the contamination of Escherichia coli in the surface waters and oysters from two cultivations of Guaratuba Bay and to analyze the correlation patterns among the concentrations of E. coli in the waters and in the oysters with the local physical-chemical parameters. Samples were collected in the spring of 2007 and summer, autumn and winter of 2008 from two points of the bay (internal point and external point). From each cultivation and sampling period, 18 oysters were collected. The samples of surface water were collected for the measurement of physical-chemical parameters ( $\mathrm{pH}$, salinity, temperature, dissolved oxygen, seston, particulate organic matter) and quantification of $\mathrm{E}$. coli. The surface water analyzed in the summer presented the largest most probable number of E. coli, (1,659.22 MPN.100 $\mathrm{ml}^{-1}$ and 958,55 MPN.100 ml at external and internal points, respectively. The oysters from the internal point presented more E. coli, except in the winter sampling. The largest contamination was observed in the spring, at the internal point $\left(979,78 \mathrm{MPN} . \mathrm{g}^{-1}\right)$. The Principal Components Analysis showed direct correlation among the amount of $\mathrm{E}$. coli in the oysters and in the surface water.
\end{abstract}

Key words: Oysters, Escherichia coli, Guaratuba Bay

\section{INTRODUCTION}

Bivalve possess an efficient filtration mechanism that allows to accumulate, from the water in what they are cultivated or extracted, countless microorganisms, thus storing a very rich microbial flora (Kinne 1983). Therefore, even though they do not get the bacterial diseases, the filter feeders mollusks can act as the carriers of microorganisms pathogenic to humans (Villalobos; Elquezabal 2000, Silva et al. 2003, Clayton 2006, Pereira et al. 2006). These organisms can accumulate several bacteria (when in polluted waters by dejections of homoeothermic animals) such as Salmonella, Escherichia, Shigella enteric virus, protozoa, etc. This makes them a public health problem, affecting the prestige of those foods by the population. Another problem is that these mollusks are mainly consumed raw or slightly cooked. Due to their biocumulative capacity, the bivalve mollusks are important bioindicators of environmental alterations, as well as biomonitors for the monitoring of the aquatic environment contamination (Liang et al. 2004).

High concentrations of $E$. coli in the bivalve ingested through the consumption of the mollusks, besides indicative of possible contamination of these organisms with the pathogenic microorganisms of hydric circulation may cause at least six types of intestinal infections (Vieira 2004). The number and type of microorganisms found in the mollusk are influenced by several factors, such as geographical location of the capture (more populous places generate larger

*Author for correspondence: forcelini@gmail.com 
contamination), season and capture method (Beirão et al. 2000).

The present study aimed to evaluate the contamination of E. coli in the water and of oysters of two cultivations in Guaratuba Bay and to analyze the correlation patterns among the concentrations of $E$. coli in the surface water and in the oysters with the local physical-chemical parameters.

\section{MATERIALS AND METHODS}

Guaratuba Bay (Fig. 1) that belongs to the homonymous municipal district, possesses an area of $50.19 \mathrm{~km}^{2}$, with the main axis oriented in the east-west direction. Its length is of approximately $16 \mathrm{~km}$, and maximum width of $3 \mathrm{~km}$, when low tide line is considered, and $10 \mathrm{~km}$, when the tide plain is included. The maximum depth of the innermost area is of $5 \mathrm{~m}$ and its communication with the Atlantic Ocean is by a narrow outlet of approximately $500 \mathrm{~m}$ of width, being limited in the north by rocky points and in the south by the Guaratuba hill. In the outlet area the depth reaches $27 \mathrm{~m}$ (Soares et. al. 1997). This estuary receives the waters of Guaratuba hydrographic basin. The basin has a density of drainage of 1.87 rivers by $\mathrm{km}^{2}$ and about $1,724 \mathrm{~km}^{2}$ of area. The two main rivers are: São João river and Cubatão river. Together they contribute with approximately 80 $\mathrm{m}^{3} / \mathrm{s}$ of fresh water to the bay (Noernberg et al. 2004). Those rivers have upper course, located in the mountainous area, with great steepness, valleys densely fit and a pattern of straight channel. The low course, located in the plains, possesses a vast valley of level bottom and a pattern of winding path (Angulo 1992).

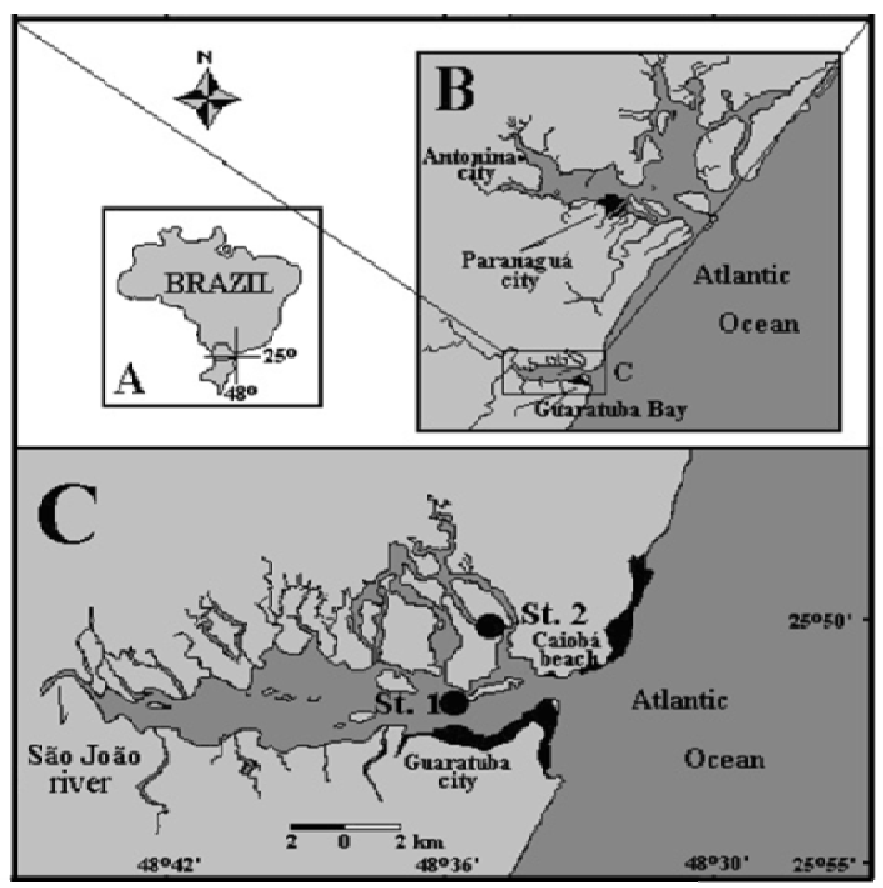

Figure 1 - A) Map of Brazil with Paraná coast location: B) Map of Paraná coast with Guaratuba Bay location; C) Map of Guaratuba Bay with the location of the sampling stations.

The flow of water of Guaratuba Bay is mainly dominated by the tide regime in the area (Santos, 2003). The tide is semidiurnal with day inequalities (Soares et al. 1995). Tide registration, made by Soares et al. (1997) for two months, in the central body of the bay, indicated medium heights at spring and neap tides of 1.5 and $0.7 \mathrm{~m}$, respectively.
Sampling in spring (11/08/2007), summer $(01 / 16 / 2008)$, autumn (04/23/2008) and winter $(06 / 30 / 2008)$ were effected and oysters were acquired from two cultivations (one in the internal section, named "internal point - St1" and other in the external section, "external point - St2") of the Guaratuba Bay. The internal point is located in a tide channel, where the hydrodynamic is lower 
when compared to the external point that is located in the outlet of the bay. At each sampling period, 18 oysters were removed from each cultivations and conditioned in the isotherm boxes until arrival in the Marine Microbiology Laboratory of the Centro de Estudos do Mar/UFPR. In each period and in each cultivations, samples of surface water were collected for the measurement of physicalchemical parameters $(\mathrm{pH}$, salinity, temperature, dissolved oxygen, seston, particulate organic matter) and quantification of E. coli.

The tidal data of Guaratuba Bay were obtained from the Marine Physic Laboratory of the Centro de Estudos do Mar/UFPR.

Daily pluviometric data of the six days that preceded the day of the sampling, including the day of the collection, were obtained through the meteorological "Guaratuba station" from the Superintendência de Desenvolvimento de Recursos Hídricos e Saneamento Ambiental (SUDERHSA). Water temperature was measured in the field, using a mercury thermometer, scale $1 / 100^{\circ} \mathrm{C}$. The salinity was measured with refractometer QA Supplies, LLC, model MT-100 ATC. The $\mathrm{pH}$ was measured using the portable $\mathrm{pH}$ meter Analion. Dissolved oxygen was analyzed by the titration according to Strickland and Parsons (1968). The samples for seston determination were filtered until the saturation of the filter and calculated through the weight difference between the empty and the full filter. The concentration of particulate organic matter was determined by the ignition technique. For the analysis of E. coli, a chromogenic substratum was used (IDEXXWP020-18) and for obtaining the most probable number (MPN) of E. coli in $100 \mathrm{ml}$ of water, a table supplied by the company Idexx Laboratories, Inc. was used.

For the microbiological analyses, the oysters were axenicaly opened and the soft parts (with the intervalvar liquids) were placed in Petri dishes of known weight and weighed in a Helmac HM 1000 scale of $0.01 \mathrm{~g}$ precision. After that distilled water was added up to $200 \mathrm{~mL}$ (weight/volume) and they were softened during one minute in the blenders, then filtered in nylon net with mesh size of 200 $\mu \mathrm{m}$. For the dilutions, $10 \mathrm{ml}$ of the filtered liquid were removed and mixed with $90 \mathrm{ml}$ of distilled water and the methodology described above for the analysis of E. coli in the water was followed. Finally, the calculations to determine the MPN of $E$. coli in each gram of oyster meat were made.
The results of physical-chemical parameters, the amount of $E$. coli in the surface water and in the oysters were submitted to a Principal Component Analysis to verify which factors influenced the amount of $E$. coli in the water and in the oysters.

\section{RESULTS}

The highest pluviosity value (129.5mm), accumulated for seven days, was observed in the autumn, followed by the summer $(109.4 \mathrm{~mm})$, and the smallest in the winter $(4.6 \mathrm{~mm})$. The highest rainfall data observed in the day of sampling was of $7.8 \mathrm{~mm}$ in the summer, followed by $0.2 \mathrm{~mm}$ in the spring and in the autumn, and the smallest was $0 \mathrm{~mm}$ in the winter (Fig. 2). Only in summer, the sampling was accomplished in wining neap tide; in other periods (spring, autumn and winter), the sampling was made in flood spring tide.

The largest tide $(100.2 \mathrm{~cm}$ in the external point) at the time of sampling was observed on the $06 / 30 / 2008$, and the smallest $(26.1 \mathrm{~cm}$ in the internal point) on 04/23/2008 (Table 1). There was little temperature difference between the two points along the four sampling periods, with low of $18.8^{\circ} \mathrm{C}$ in the third collection (winter) in the internal point and maximum of $27^{\circ} \mathrm{C}$ in the second sampling (summer) in the external point (Table 1). The smallest salinity (12.6) was observed in the internal point in sampling of 01/16/2008 (summer), and the largest (34.6) in the sampling of $30 / 06 / 2008$ (winter), in the external point. The salinities were higher in the external point than in the internal, except in autumn (Table 1). The $\mathrm{pH}$ was almost constant among the sampled periods; however, there was a small increase (8.25) at the external point in the winter sampling. The smallest value (7.31) was at the internal point in the summer sampling (Table 1).

There was little variation in the saturation percentage of dissolved oxygen in the spring and autumn sampling. However, at the external point, in autumn, the largest saturation percentage was observed $(163.7 \%)$. The smallest was $59.5 \%$ at the internal point in the fourth sampling (Table 1). Seston highest values, with a maximum of 261.9 mg. $l^{-1}$ were observed in the second sampling day (summer) and the smallest ones, with a minimum of $17.7 \mathrm{mg} . \mathrm{l}^{-1}$, in the winter sampling, both at the internal point (Table 1).

The particulate organic matter was higher at the external point in almost all the samplings. 
Exception was in the summer, where the value was larger at the internal point. The smallest values were observed in the autumn sampling $(0.1204$ $\mathrm{mg} . \mathrm{l}^{-1}$ at the internal point and $0.1210 \mathrm{mg} . \mathrm{l}^{-1}$ at the external point). The largest were registered in the fourth sampling $\left(0.1236 \mathrm{mg} . \mathrm{l}^{-1}\right.$ at the internal point and $0.1255 \mathrm{mg} . \mathrm{l}^{-1}$ at the external point) (Table 1). The surface water analyzed in the winter presented the smallest MPN of E. coli (36.66 MPN.100 ml at the internal point and $72.32 \mathrm{MPN} .100 \mathrm{ml}^{-1}$ at the external point). In spring and autumn, the values of these microorganisms were intermediate; however, they were always higher at the internal point (124.88 MPN.100 ml ${ }^{-1}$ and 340.55 MPN.100 $\mathrm{ml}^{-1}$, respectively). Its higher values were in summer (1.659.22 MPN.100 ml $\mathrm{ml}^{-1}$ at the external point and 958.55 MPN.100 ml ${ }^{-1}$ at the internal point) (Table 1).

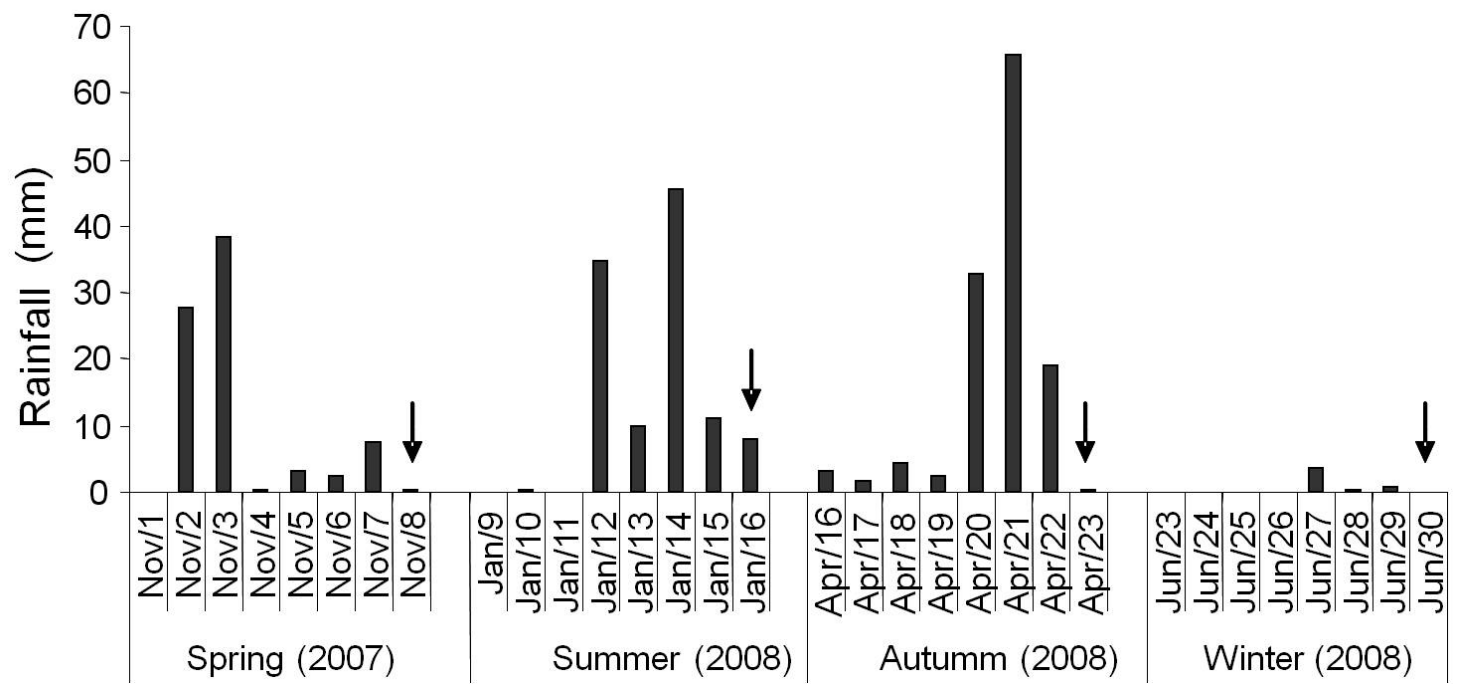

Figure 2 - Pluviometric data for seasons of the year, of six days that preceded sampling. Arrows indicate the day of sampling.

Table 1 - Mean of three replicates of tide, temperature, salinity, $\mathrm{pH}$, dissolved oxygen, seston, particulate organic matter, E. coli values in surface water and E. coli in oyster meat in the four samplings effected in the internal and external points of Guaratuba Bay.

\begin{tabular}{|c|c|c|c|c|c|c|c|c|}
\hline \multirow{2}{*}{$\begin{array}{c}\text { Samples } \\
\text { Point }\end{array}$} & \multicolumn{2}{|c|}{$11 / 08 / 2007$} & \multicolumn{2}{|c|}{$01 / 16 / 2008$} & \multicolumn{2}{|c|}{ 04/23/2008 } & \multicolumn{2}{|c|}{ 06/30/2008 } \\
\hline & Internal & External & Internal & External & Internal & External & Internal & External \\
\hline Tide $(\mathrm{cm})$ & 73.4 & 84.0 & 63.8 & 59.0 & 26.1 & 31.3 & 84.4 & 100.2 \\
\hline Temperature $\left({ }^{\circ} \mathrm{C}\right)$ & 24.3 & 25.0 & 26.8 & 27.0 & 23.5 & 22.5 & 18.8 & 19.1 \\
\hline Salinity & 20.0 & 22.3 & 12.6 & 14.6 & 22.3 & 18.0 & 28.0 & 34.6 \\
\hline pH & 7.35 & 7.68 & 7.31 & 7.73 & 7.62 & 7.93 & 7.98 & 8.25 \\
\hline DO $(\%)$ & 125.91 & 154.80 & 90.29 & 116.56 & 129.70 & 163.70 & 59.58 & 72.39 \\
\hline Seston $\left(\mathrm{mg.l}^{\mathbf{l}^{-1}}\right)$ & 160.20 & 104.10 & 261.96 & 256.36 & 54.13 & 45.20 & 17.70 & 27.16 \\
\hline POM (mg.L $\left.L^{-1}\right)$ & 0.1230 & 0.1241 & 0.1220 & 0.1208 & 0.1204 & 0.1210 & 0.1236 & 0.1255 \\
\hline $\begin{array}{c}\text { E. coli water } \\
\left(\mathrm{MPN} .100 \mathrm{~mL}^{-1}\right)\end{array}$ & 124.88 & 61.77 & 958.55 & 1659.22 & 180.22 & 340.55 & 36.66 & 72.32 \\
\hline $\begin{array}{c}\text { E. coli oyster } \\
\left(\text { MPN.g }^{-1}\right)\end{array}$ & 979.78 & 112.20 & 894.73 & 827.96 & 597.79 & 296.08 & 0.85 & 3.70 \\
\hline
\end{tabular}

Oysters collected at the internal point presented more E. coli, except in the winter sampling. The higher contamination was observed in the spring at the internal point $\left(979.78 \mathrm{MPN} . \mathrm{g}^{-1}\right)$. The smallest value was observed at the internal point in winter $\left(0.85{\left.\mathrm{MPN} . \mathrm{g}^{-1}\right)}^{-1}\right.$ (Table 1).

The first component of PCA results explained $66.4 \%$ of the data variation and showed a positive 
correlation among the salinity and $\mathrm{pH}$, and a negative correlation of pluviosity, temperature and $E$. coli in the water and in the oysters at the two sampling points in the winter. Inverse results were observed at the two points during the summer (Fig. $3)$.

The second component explained $15.6 \%$ of the variation and showed a positive correlation of dissolved oxygen and negative of the tide and of the organic matter at the two points during the autumn. In the spring, positive correlation was observed with the seston and temperature at the internal point. The values of the physical-chemical and biological parameters registered at the external point in the spring did not change (Fig. 3).

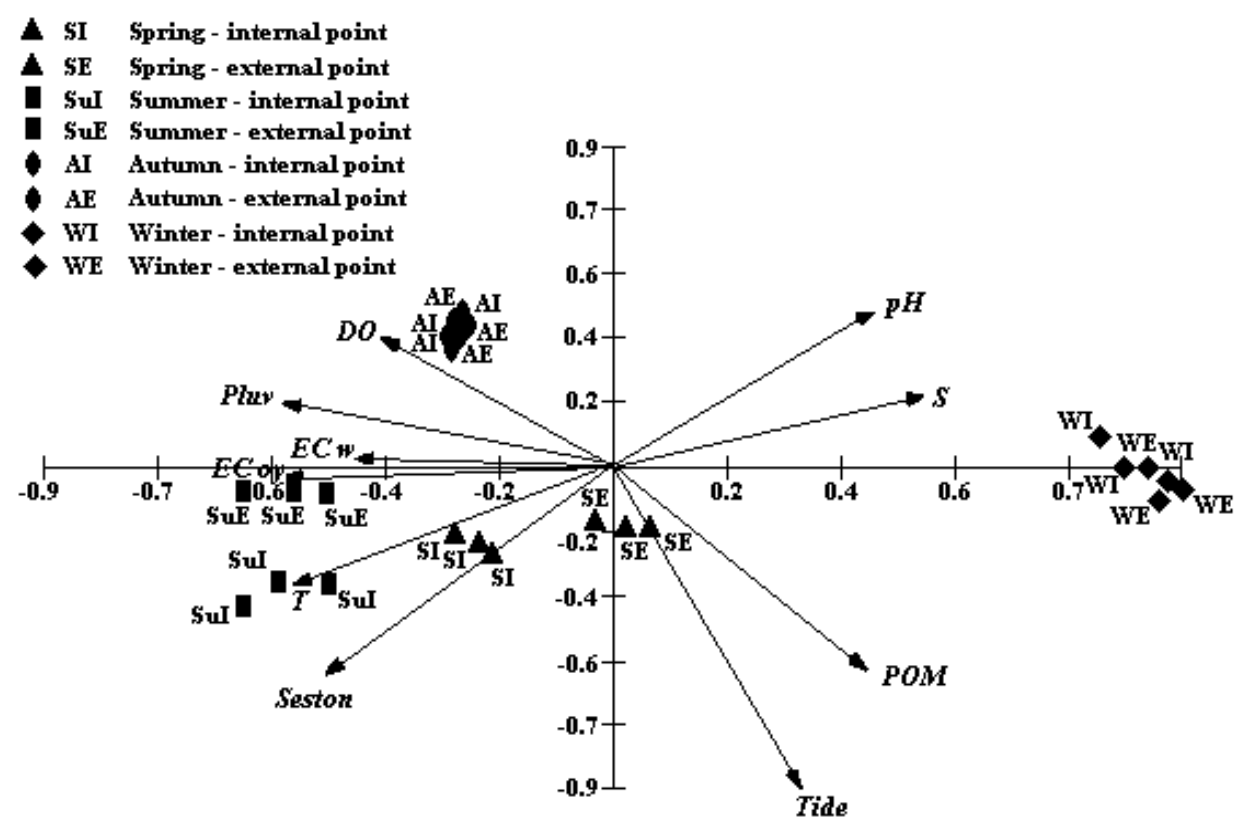

Figure 3 - Principal Component Analysis of the studied physical-chemical and biological parameters

\section{DISCUSSION}

Salinity values, larger at the external point and smaller at the internal point, were similar to those reported by Santos (2003) who studied the physical-chemical and microbiological parameters in July and August 2002 in the surface waters of Guaratuba Bay at the same places as the present work. The salinities observed in this work were inverse to those observed by Christo (2006), while this was the largest values in the summer samples in the present research they were registered in the winter. Such differences could be related to the low amount of rains in the winter of 2008 . Difference in tide height might have influenced this result since the maximum tide height was observed in the winter and only in summer the sampling was accomplished in the wining tide.

Seston and $\mathrm{pH}$ results differed from the observation of Santos (2003) who reported equal $\mathrm{pH}$ values (7.82) for both the stations, in this study values were always higher at the external station. Differences were also noted in relationship to seston amount in the water. Santos (2003) registered much higher values at the internal station, which were similar when compared period to period in this work, and always smaller than observed in the above mentioned work in the winter sampling.

Dissolved oxygen results were always higher at the external station than at the internal. While at the external station, it was directly influenced by the adjacent continental platform water, more saline, poorer in nutrients and richer in dissolved oxygen, the internal station was located in a tide channel receiving great influence of adjacent river waters, and according to Christo (2006), with smaller transparency. Such characteristics 
indicated that the amount of dissolved oxygen was influenced directly by the local conditions. It would be important to mention that the waters of the external point were more agitated than the waters at the internal point and therefore, favoring a larger introduction to the superficial waters, of oxygen originating from the air. Still comparing the values of dissolved oxygen obtained in this work in the winter with those reported by Santos (2003), it could be observed that at the two stations, values close to $100 \%$ of saturation and around of $50 \%$ (in the present work) were very smaller. Such results could be related with the absence of the rains and consequent reduction of the water originating from the rivers in the days previous to sampling in the winter of 2008. It would be important to point out although that the largest amount of particulate organic matter was also registered in the winter. High amounts of organic matter tend to favor an increase of heterotrophic bacteria, thus contributing to a quantitative reduction of the dissolved oxygen.

Christo (2006) found higher values of $E$. coli at the internal station and smaller at the external. Similar characteristics were observed by Santos (2003) in the winter of the same year. Different results were observed in this work where, in the spring, autumn and winter sampling, the values were low at the two places. However, in the summer sampling, there was a significant increase of $E$. coli, mainly at the external point. Different results were expected as, between 2002 and 2008, a sewer treatment system was implanted in Guaratuba. However, according to Wilson Barion (personal comunication) from Companhia de Saneamento do Paraná (SANEPAR), the works of sewers ducts contemplated $45 \%$ of the city, at the time of the present work, acting mainly in the central areas and summer vacation neighborhoods. As the area around Guaratuba Bay was still deficient in collection and sewer treatment, good part of the served effluents were being spilled in thebay's waters. Besides, there were deficiencies in the collection system and treatment of sewer originating from Caiobá, neighborhood of the municipal district of Matinhos, located at the entrance of Guaratuba Bay and frequently visited by summer vacationists. Additional problem was caused by the high number of tourists that visited the municipal districts of Guaratuba and Matinhos during the summer, thus increasing the amount of served waters that should be treated and not just thrown directly in the bay. During this period, the waters of the area were still mainly considered inappropriate for bathing by the Instituto Ambiental do Paraná (IAP), what corroborated with the results obtained in this study. In spite of the number of samples analyzed in this work, it was smaller than demanded by the Resolution no. 357 (Brazil, 2005), -"the geometric average concentration of the density of fecal coliforms (termotolerants) from a minimum of 15 saline water samples collected in the same place, in which natural or intensive cultivation of organisms that are to be consumed by humans, cannot exceed $43 \mathrm{in} 100 \mathrm{ml}$ and the percentile $90 \%$ cannot exceed 88 termo-tolerant coliforms in 100 milliliters. Those indexes should be maintained in a minimum of five samples during an annual monitoring". The amount of E. coli in all the studied periods was larger than the established limits by the referred resolution, indicating that the studied points were not proper for bivalve cultivation. The amount of $E$. coli was above than the allowed by the American legislation that evaluated the microbiological conditions of the cultivations waters (NSSP, 2003).Many studies have shown an inverse correlation among the amounts of E. coli in the water and in the oysters. Kolm and Absher (2008) compared the amount of E. coli in native species (C. brasiliana and C. rhizophorae) and in the adjacent water where they were collected in the Paranaguá Bay and concluded that in the months with higher values of coliforms indexes in oysters (summer) the values were lower in the water. Faria (2002), studied C. gigas originating from the cultivations in Babitonga Bay - SC found higher values of E. coli in the water in the autumn and winter and in the oysters in summer. Siqueira (2008) analyzed the oysters' seed of Crassostrea genus from the estuary of Vaza-Barris River - SE and found high values of thermo-tolerant coliforms in the water and low in the seeds in the rainy period and an inverse relationship in the dry period. Vieira (2008) analyzed total coliforms and thermo-tolerants in the waters and $C$. rhizophorae from Rio Pacoti's estuary - CE showed that the contamination of the cultivation water was larger than the one of the oysters. However, those correlations were not observed in the present study, where the amounts of E. coli in the oysters and in the water were mainly larger in the summer. According to Absher (pers. com.), the direct correlation found in this work could be related with the increase in the amount of tourists in the summer period that resulted an increase in the 
amount of sewers produced and possibly spilled in the Bay without any treatment. The winning tide registered in the day of the summer sampling might also have influenced the amount of $E$. coli found in the oysters and in the surface water, since according to Andrews (1979), the oysters possessed a filtration capacity larger than 400 liters/day.

Silva et al. (2003) studied (between March and October 2002) C. rhizophorae from a cultivation located in the estuary of Rio Cocó-CE and observed contaminations between $<1.8$ and 920 $\mathrm{NMP} / \mathrm{g}$ of fecal coliforms in the oysters, very close values found in the present study, which was between 0.85 and $979.7 \mathrm{MPN} / \mathrm{g}$.

Considering the actual national legislation, the Resolution - RDC n 12, of January 2, 2001 of the Agência Nacional de Vigilância Sanitária (ANVISA) only foresees Staphylococcus coagulates positive and Salmonella sp. limits in mollusks bivalve "in natura", colds or frozen, not consumed raw (Brazil, 2001). However, it is known that the Brazilian population has the habit of the ingestion of raw oysters or open in steam. Thus, it could be suggested that urgent alterations must be made in the legislation, including the limits of thermo-tolerant coliforms and/or E. coli in bivalve to be consumed without cooking.

\section{REFERENCES}

Andrews JD. Pelecypoda: Ostreidae. New York: Academic Press; 1979.

Angulo JR. Geologia da planície costeira do Estado do Paraná (PhD Thesis). São Paulo: Universidade de São Paulo;1992.

Beirão H, Teixeira E, Meinert EM, et al. Processamento e Industrialização de Moluscos. Campinas: ITAL, Centro de Tecnologia de Carnes; 2000.

Brasil. Agência Nacional de Vigilância Sanitária (ANVISA) - Resolução - RDC no 12, de 2 de janeiro de 2001[Internet]. Accessed in 2009 FEB. Available from:

http://www.anvisa.gov.br/legis/resol/12_01rdc.htm.

Brasil. Conselho Nacional do Meio Ambiente (CONAMA). - Resolução no 375, de 17 de março de 2005 [Internet]. Accessed in 2009 MAR. Available from: http://www.mma.gov.br/port/conama/ legiabre.cfm?codlegi $=459$

Christo SW. Biologia reprodutiva e ecologia de ostras do gênero Crassostrea sacco, 1897 na Baía de Guaratuba (Paraná - Brasil): Um subsídio ao cultivo (PhD Thesis). Curitiba: Universidade Federal do Federal; 2006.
Clayton WEL. Microbial Source Tracking- The use of new research tools for the identification and tracking of bacterial pollution sources affecting shellfish culture opportunities. Mar Ecoyss Aquacult. 2006; 97.

Faria JM. Estudo da qualidade bacteriológica da água e das ostras (Crassostrea gigas) cultivadas na Baía da Babitonga e sua adequação para fins de consumo (Master Thesis). Joinville: Universidade da Região de Joinville; 2002.

Kinne O. Diseases of marine animals. Hamburg: Biologische Anstalt Helgolan; 1983.

Kolm HE, Absher, TM. Bacterial density and coliform organisms in waters and oysters of Paranaguá Estuarine Complex, Paraná, Brazil. Bol Inst Pesca. 2008; 34: 49 - 59.

Liang LN, He B, Jiang GB, Chen DY, Yao ZW. Evaluation of mollusk as biomonitors to investigate heavy metal contamination along the Chinese Bohai Sea. Sci Total Environ. 2004; 324:105-113.

National Shellfish Sanitation Program - NSSP. Guide for the Control of Molluscan Shellfish. [Internet]. Accessed in: 2008 DEC. Available from: http://www.cfsan.fda.gov

Noernberg M, Marone E, Lautert LFdeC, Brandini N, Angelotti R. Caracterização da estratificação salina na Baía de Guaratuba-PR. In: Congresso Brasileiro De Oceanografia. 2004 Oct; Itajaí: Associação Brasileira de Oceanografia: AOCEANO; 2004.

Pereira MA, Nunes MM, Nuernberg L, Schulz D, Batista CRV. Microbiological quality of oysters (Crassostrea gigas) produced and commercialized in the coastal region of Florianópolis - Brazil. Braz. J. Microbiol. 2006; 37: 159-163.

Santos PRNdeMdos. Variação espaço-temporal do bacterioplâncton e espacial do bacteriobentos da baía de Guaratuba, Paraná, Brasil (Master Thesis). Curitiba: Universidade Federal do Paraná; 2003.

Silva AIM, Vieira RHSF, Menezes FGR, FontelesFilho AA, Torres RCO. Bacteria of fecal origin in mangrove oyesters (Crassostrea rhizophorae) in tge Cocó River esturay, Ceará State, Brazil.. Braz. J. Microbiol. 2003; 34:126-130.

Siqueira KLF. Avaliação do sistema de cultivo de ostra do gênero Crassostrea (SACCO, 1897) no estuário do Rio Vaza-Barris (Sergipe) (Master Thesis). Aracaju: Universidade de Tiradentes; 2008.

Soares CR, Angulo RJ, Lessa GC. Roteiro de excursão ao litoral do estado do Paraná. Morfodinâmica de ambientes atuais, evolução da planície durante o quaternário e problemas de erosão costeira. Trabalho apresentado no In: VI Congresso da Associação Brasileira de Estudos do Quaternário e Reunião Sobre o Quaternário da América do Sul. Curitiba. 1997 Aug; Curitiba: Associação Brasileira de Estudos do Quaternário: ABEQUA; 1997. 
Soares CR, Camargo R, Marone E. O Problema de assoreamento na Marina do Sol, Município de Guaratuba (PR). Bol Paran Geoc 1995; 43: 61-77.

Strickland JD, Parsons TRA. Practical handbook of sea water analysis. Bull Fish Res. 1968;167.

Vieira RHSF. Microbiologia, higiene e qualidade do pescado: teoria e prática. São Paulo: Varela; 2004.

Vieira RHSF, Atayde MA, Carvalho EMRde, Fontaneles Filho AD. Contaminação fecal da ostra Crassostrea rhizophorae e da água de cultivo do estuário do Rio Pacoti (Eusébio, Estado do Ceará): Isolamento e identificação de Escherichia coli e sua susceptibilidade a diferentes antimicrobianos. Braz, J Vet. Res Anim Sci. 2008; 45: 180-189.
Villalobos LB, Elquezabal L. Detección de posible Escherichia coli enteropatógena en el bivalvo Pinctada imbricata comercializado en Cumaná, Venezuela. Bol Inst Oceanogr. 2000; 39: 17-23.

Received: December 20, 2011; Revised: March 20, 2012; Accepted: October 18, 2012. 